\title{
Chlorite-illite/muscovite interlayered and interstratified crystals: A TEM/STEM study*
}

\author{
Jung Hoo Lee ${ }^{1}$, Donald R. Peacor ${ }^{1}$, Daniel D. Lewis ${ }^{2,3}$, and Robert P. Wintsch ${ }^{2}$ \\ ${ }^{1}$ Department of Geological Sciences, The University of Michigan, Ann Arbor, Michigan 48109, USA \\ ${ }^{2}$ Department of Geology, Indiana University, Bloomington, Indiana 47405, USA
}

\begin{abstract}
Phyllosilicates in rocks which are transitional from mudstone to slate from Lehigh Gap, Pa., have been studied by a variety of techniques, including high resolution Transmission Electron Microscopy and Analytical Electron Microscopy. The principal minerals are "white mica" which is transitional from illite in mudstone to ordered twolayer mica in slate, and chlorite. $7 \AA ̊$ berthierine occurs more rarely. Dioctahedral and trioctahedral layers are shown to be interleaved in individual crystals at all scales between the following two end members: (1) both random and regular 1:1 interlayering at the scale of individual layers, as shown, in part, by lattice fringe images. (2) packets of trioctahedral and dioctahedral layers up to a few thousand Ångstroms or microns in thickness, detectable with ordinary optical techniques. The complete range of intermediate structures is represented in samples which are in transition to slate. Bulk analytical (EMPA), X-ray diffraction or other measurements are shown to result in averages over both kinds of layers when TEM techniques are not used.
\end{abstract}

\section{Introduction}

Clay minerals commonly occur as regular or random intergrowths of layers of more than one species. Smectite-illite and chlorite-vermiculite are two such well studied and characterized examples. Where interlayering occurs it is generally assumed that there is no significant difference in octahedral site chemistry; i.e., intergrowths are either of dominantly trioctahedral or dioctahedral layers. This is in part due to the fact that most methods of study involve measurements of properties averaged over many grains; e.g., powder X-ray diffraction, ion exchange or chemical analysis. Limited numbers of trioctahedral layers interleaved with dominant dioctahedral layers or vice versa, can generally not be detected. In such a case X-ray diffraction would give evidence of the structure only of the dominant structure and chemical data would therefore be interpreted only on the basis of that structure, although it actually would represent an average over several structure types. The interpretation of such data would therefore be subject to error.

\footnotetext{
* Contribution No. 400 from the Mineralogical Laboratory, Department of Geological Sciences, The University of Michigan

3 Present address: Exon Company USA, P.O. Box 120, Denver, Colorado 80201, USA

offprint requests to: Dr. Jung Hoo Lee
}

In order to characterize the specific nature of individual layers or packets of layers it is necessary to directly image layers using transmission electron microscopy (TEM) techniques. Even this does not generally permit identification of trioctahedral and/or dioctahedral components. However, with high-resolution analytical electron microscopy (AEM) performed with a scanning transmission electron microscope (STEM), which also can be operated in TEM mode, it is possible to achieve analytical resolution approaching $300 \AA$ (approximately 30 layers of $10 \AA$ structure). Interlayering between illite and chlorite at a TEM level is reported by Page and Wenk (1979), Knipe (1981) and Lee et al. (1982b). Other types of trioctahedral-dioctahedral interlayering were also described by many others (Bailey 1982; Craw et al. 1982; Iijima and Zhu 1982; Veblen 1983).

We have applied TEM and AEM techniques to the mudstone to slate transition in the Martinsburg Formation at Lehigh Gap, Pennsylvania. Here, chlorite and "white mica" (a continuous sequence of phases from illite to muscovite) occur in a variety of intergrowths at all scales, from both regular and random intergrowths at the individual layer scale (in mudstone), to interstratified packets of chlorite and muscovite in grains of size greater than $1 \mu \mathrm{m}$. The latter can be detected optically as relatively large and well crystallized single-phase crystals (in slate).

The results reported in this study are part of a general study of slaty cleavage development in the Pen Argyl member of the Martinsburg Formation near Lehigh Gap, Pennsylvania. Our materials are primarily from an outcrop of this member located at Lehigh Gap along the abandoned grade of the Lehigh and New England Railroad overlooking Pennsyslvania Route 29/248. The significance of the rocks at this locality is that the Martinsburg Formation changes from a mudstone to a slate over a few tens of meters from the faulted, unconformable contact with the overlying Shawangunk Formation (Epstein and Epstein 1969). These rocks therefore provide a continuous exposure from mudstone to slate where the mineralogical changes attendant to the conversion of mudstone to slate may be studied.

The orientation of the phyllosilicates at Lehigh Gap has been well characterized by Holeywell and Tullis (1975) using an X-ray pole figure device. They found three preferred orientations of phyllosilicates. In the mudstone near the Shawangunk-Martinsburg contact, white mica parallels the bedding plane while chlorite grains are oriented twenty degrees more steeply than the bedding. Further from the 
contact and as the slaty cleavage develops, white mica gradually attains the orientation of macroscopic slaty cleavage but chlorite retains its former orientation until approximately 30 meters further down the outcrop. Holeywell and Tullis suggest that some form of selective recrystallization must be responsible for the different behavior of "white mica" and chlorite in these rocks.

\section{Materials and methods of study}

The samples studied include 18 random and 9 oriented samples from 18 regularly spaced intervals at Lehigh Gap. In addition, six hand samples and four oriented samples were collected from five slate quarries and one roadcut to the south of Lehigh Gap.

Polished thin sections for electron microprobe analysis and petrographic thin sections were obtained with surfaces perpendicular to the line of intersection of bedding and cleavage. Samples for TEM and AEM investigation were prepared by first obtaining oriented polished thin sections. Following optical examination, washers were attached to selected areas and the areas with the washers were separated from the glass backing. These thin-section areas were then ion-thinned. As the c-axes of phyllosilicates are preferentially oriented normal to bedding or cleavage, this procedure resulted in orientations with $c^{*}$ normal to the beam direction in the electron microscope. Thus, the layering could be studied through the use of lattice fringe imaging with $00 l$ reflections.

Electron microprobe data were obtained for nine elements using a three spectrometer Etec Autoprobe under conditions outlined by Klein (1974). Standards were synthetic diopside for $\mathrm{Mg}, \mathrm{Ca}$ and $\mathrm{Ti}$; natural albite for $\mathrm{Na}$; synthetic $\mathrm{KAlSi}_{3} \mathrm{O}_{8}$ for $\mathrm{K}$; natural kyanite for $\mathrm{Si}$ and $\mathrm{Al}$; natural rhodonite for $\mathrm{Mn}$; and natural hedenbergite for $\mathrm{Fe}$. Data were reduced using the Bence-Albee method.

Powder X-ray diffractometer data were obtained on $90 \%$ pure mineral separates in order to identify the phyllosilicates and other minerals occurring in all grain sizes. Samples were prepared by gently packing powders into a standard aluminum specimen holder in order to minimize preferred orientation.

The electron microscope used is a JEOL JEM-100CX scanning transmission electron microscope (STEM) fitted with a solid state detector for energy dispersive analysis (EDA). It has routine TEM point-to-point resolution of $3.4 \AA$ and can attain up to $1.5 \AA$ with a high resolution pole piece. The microscope has been extensively modified (see Blake et al. 1980 or Allard and Blake 1982) in order to eliminate production of X-rays from other than the area of the sample exposed to the beam and thus to obtain accurate analytical data with a spatial resolution of up to $300 \AA$. The general analytical procedures are discussed in Isaacs et al. (1981). It is important to emphasize that ratios of element concentrations to $\mathrm{Si}$ are measured (Cliff and Lormer 1975) and that as long as thin edges of specimens (less than approximately 4,000 $\AA$ in thickness) are studied, the ZAF effects are less than 10 percent (Goldstein et al. 1977).

\section{X-ray diffraction and optical studies}

Most of the phyllosilicate grains are present in sizes below the level of resolution of the electron microprobe. However, in mudstone samples (which have no slaty cleavage) there is a population of grains which are oriented approximately parallel to the bedding and which are commonly larger than $20 \mu \mathrm{m}$ in diameter and $10 \mu \mathrm{m}$ in thickness. These grains optically appear to consist of white mica and chlorite as single structures or as grains which are parallel intergrowths of chlorite and white mica. In samples which have well developed slaty cleavage the majority of the phyllosilicate grains, whether oriented parallel to bedding or to cleavage, are also in sizes below the level of resolution by electron microprobe analysis. However, they retain the large grains parallel to bedding, and also contain grains of equivalent size parallel or sub-parallel to the plane of cleavage. These, at a TEM level, also consist of white mica, chlorite, and interlayered chlorite-white mica. A grain of the latter is shown in Fig. 1. It appears to consist of well defined and differentiated subunits of white mica and chlorite. Likewise the separate white micas and chlorites appear to be homogeneous at the optical level of resolution. The powder X-ray diffraction patterns also verify that the only detectable phyllosilicates occurring in all samples are chlorite and a white mica.

The peaks attributed to a "white mica" were qualitatively similar to those of an illite in the mudstone samples but those in the slate sample were typical of muscovite. A more quantitative measure of this apparent trend was obtained using the "sharpness ratio" of Weaver (1960) and this is consistent with the qualitative observations. Mica polytypes were identified using the criteria of Yoder and Eugster (1955), showing that both $1 \mathrm{M}$ and $2 \mathrm{M}$ polytypes are present in mudstone samples but that only $2 \mathrm{M}$ can be detected in slates. In addition, the intensity ratio of the $2.80 \AA$ peak $(11 \overline{6}$ reflection of $2 \mathrm{M})$ to that of $2.58 \AA$ (combination of $1 \overline{3} 1,116,20 \overline{2}$ reflections of $2 \mathrm{M}$ and $13 \overline{1}, 130$ of $1 \mathrm{M}$ ) increases away from the Martinsburg-Shawangunk contact, although the increase is only apparent in quarry samples (slate). Maxwell and Hower (1967) showed that this is consistent with an increase in the proportion of $2 \mathrm{M}$ relative to $1 \mathrm{M}_{\mathrm{d}}$ in mixtures of the two. The X-ray data therefore show that the white mica varies from a typical illite in mudstones near the contact to well-ordered muscovite in slates.

\section{Electron microprobe analysis}

The only phyllosilicate grains which were large enough to be resolved using the electron microprobe were the large megacrysts parallel to bedding in the mudstone and slate, and those parallel to the cleavage in the slate. This is a small proportion of all of the phyllosilicates and therefore may not be representative of average values of a sample. The small grain-size problems were compounded by the presence of mica-chlorite intergrowths. Therefore, analyses of chlorite with more than $0.5 \mathrm{wt} . \% \mathrm{~K}_{2} \mathrm{O}$ and those of white mica with less than $7.0 \% \mathrm{~K}_{2} \mathrm{O}$ were discarded on the assumption that they were contaminated due to intergrowths of the other phase. Analyses which did not sum to approximately $100 \%$ (including $\mathrm{H}_{2} \mathrm{O}$ ) were also discarded. As a result, only one quarter of all analyses (approximately 400 ) was believed to be reliable. Several analyses for a given sample were averaged in order to get the results shown in Tables 1 and 2.

The analyses of the white mica show considerable $\mathrm{Fe}$ and $\mathrm{Mg}$. The $\mathrm{Fe}$ and $\mathrm{Mg}$ in the analyses may be interpreted as reflecting solid solution toward phengite. Velde (1965) reported a wide stability field for phengite from his experiments with natural and synthetic material. $\mathrm{He}$ also noted that natural phengite commonly forms at high pressure and low temperature as in blue schist rocks and that synthetic celadonite-muscovites show greater $\mathrm{Fe}-\mathrm{Mg}$ solid solution at higher pressures. Guidotti (1973), from the study of metamorphic rocks ranging from the upper staurolite to the upper sillimanite zone, reported that an increase in phengite content of muscovite is caused by an increase in pressure but it is not affected significantly by an increase 


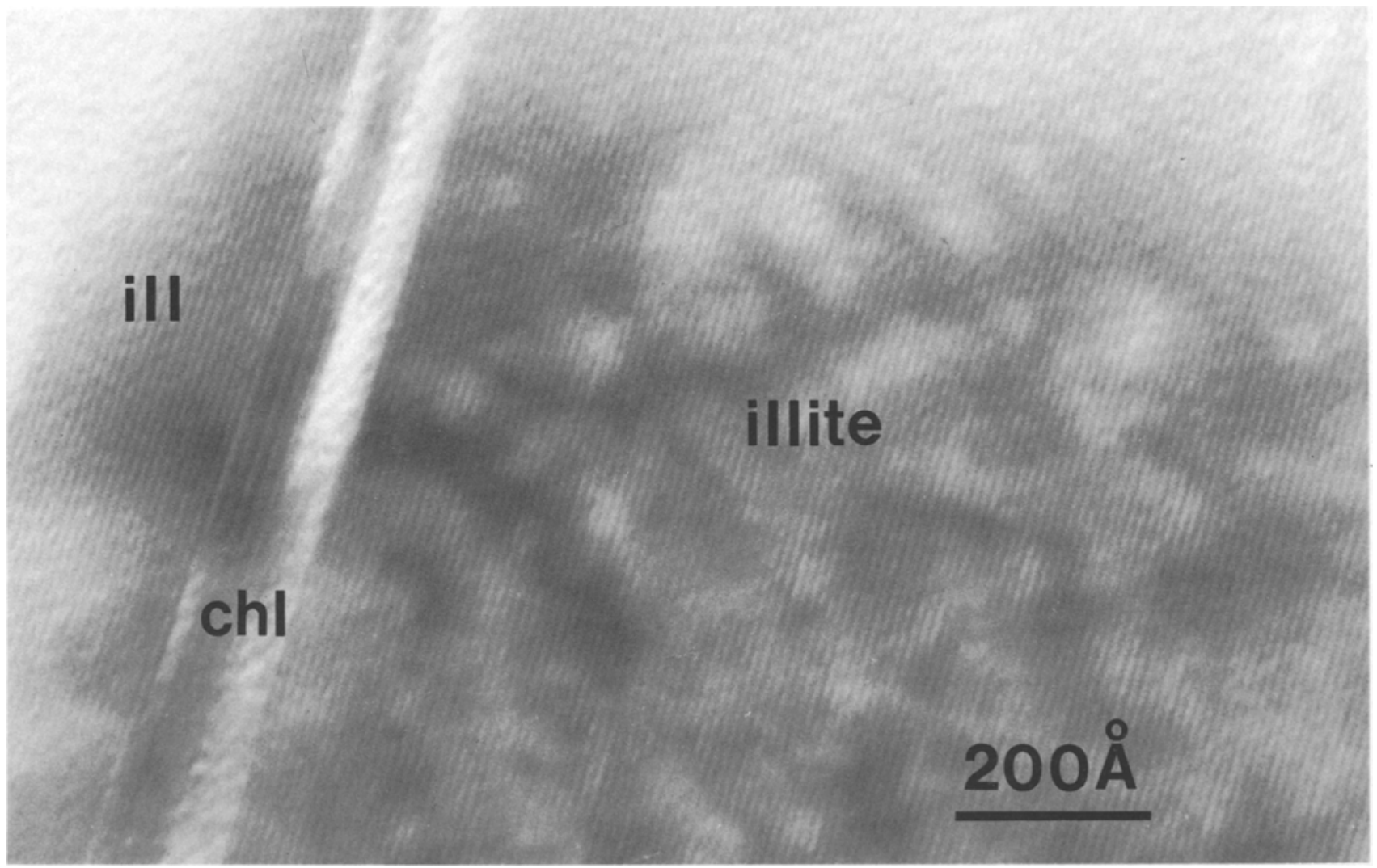

Fig. 1. A TEM $00 l$ lattice-fringe image showing a small packet of chlorite layers within an ilite grain. Layers of illite and chlorite are semicoherent. Protions of chlorite near the interface were damaged by the electron beam and show no contrast. The sample is from mudstone

Table 1. Average electron microprobe analyses of illite mega-grains

\begin{tabular}{|c|c|c|c|c|c|c|c|}
\hline & \multirow{2}{*}{$\begin{array}{l}\text { Mudstone } \\
\text { LG4 (4) } \\
\text { (bedding) }\end{array}$} & \multirow{2}{*}{$\begin{array}{l}\text { Transitional } \\
\text { LG10 (7) } \\
\text { (bedding) }\end{array}$} & \multicolumn{5}{|l|}{ Slate } \\
\hline & & & $\begin{array}{l}\text { LG20 (4) } \\
\text { (bedding) }\end{array}$ & $\begin{array}{l}\text { Q1 (3) } \\
\text { (bedding) }\end{array}$ & $\begin{array}{l}\text { Q1 (14) } \\
\text { (cleavage) }\end{array}$ & $\begin{array}{l}\text { Q2 (5) } \\
\text { (bedding) }\end{array}$ & $\begin{array}{l}\text { Q2 (1) } \\
\text { (cleavage) }\end{array}$ \\
\hline $\mathrm{SiO}_{2}$ & $46.3(2.2)^{b}$ & $49.2(1.8)$ & $49.8(1.1)$ & $44.4(0.9)$ & $46.2(1.6)$ & 45.1 & $45.9(1.1)$ \\
\hline $\mathrm{TiO}_{2}$ & $0.3(0.1)$ & $0.2(0.2)$ & $0.1(0.1)$ & $0.3(0.2)$ & $0.3(0.2)$ & 0.4 & $0.4(0.2)$ \\
\hline $\mathrm{Al}_{2} \mathrm{O}_{3}$ & $33.4(3.0)$ & $30.9(2.6)$ & $29.3(1.4)$ & $32.2(3.1)$ & $33.5(2.1)$ & 30.6 & $30.6(1.2)$ \\
\hline $\mathrm{FeO}$ & $3.8(2.8)$ & $3.7(1.1)$ & $2.7(0.9)$ & $4.8(1.6)$ & $2.4(1.3)$ & 5.7 & $5.1(1.4)$ \\
\hline $\mathrm{MnO}$ & $0.1(0.1)$ & 0.0 & $0.1(0.0)$ & 0.0 & $0.1(0.0)$ & 0.2 & $0.1(0.1)$ \\
\hline $\mathrm{MgO}$ & $1.1(0.9)$ & $1.7(0.7)$ & $2.6(0.3)$ & $1.7(1.2)$ & $1.1(0.9)$ & 2.0 & $1.6(0.4)$ \\
\hline $\mathrm{CaO}$ & 0.0 & 0.0 & 0.0 & 0.0 & 0.0 & 0.0 & 0.0 \\
\hline $\mathrm{Na}_{2} \mathrm{O}$ & $0.1(0.1)$ & $0.3(0.4)$ & $0.1(0.1)$ & $0.3(0.3)$ & $0.4(0.2)$ & 0.0 & $0.1(0.2)$ \\
\hline $\mathrm{K}_{2} \mathrm{O}$ & $9.1(0.6)$ & $8.1(0.6)$ & $7.9(0.8)$ & $9.5(0.1)$ & $8.8(0.5)$ & 8.4 & $9.1(0.3)$ \\
\hline Total & 94.2 & 94.1 & 92.6 & 93.2 & 92.8 & 92.4 & 92.9 \\
\hline $\mathrm{Si}$ & $6.2^{\circ}$ & 6.5 & 6.6 & 5.9 & 6.1 & 6.0 & 6.2 \\
\hline Al IV & 1.8 & 1.5 & 1.4 & 2.1 & 1.9 & 2.0 & 1.8 \\
\hline Al VI & 3.4 & 3.3 & 3.2 & 3.0 & 3.3 & 2.8 & 3.1 \\
\hline $\mathrm{Ti}$ & 0.0 & 0.0 & 0.0 & 0.0 & 0.0 & 0.1 & 0.0 \\
\hline $\mathrm{Fe}$ & 0.4 & 0.4 & 0.3 & 0.6 & 0.4 & 0.7 & 0.6 \\
\hline $\mathrm{Mn}$ & 0.0 & 0.0 & 0.0 & 0.0 & 0.0 & 0.0 & 0.0 \\
\hline $\mathrm{Mg}$ & 0.2 & 0.3 & 0.5 & 0.4 & 0.3 & 0.4 & 0.3 \\
\hline $\mathrm{Ca}$ & 0.0 & 0.0 & 0.0 & 0.0 & 0.0 & 0.0 & 0.0 \\
\hline $\mathrm{Na}$ & 0.0 & 0.1 & 0.2 & 0.1 & 0.1 & 0.0 & 0.0 \\
\hline $\mathrm{K}$ & 1.6 & 1.4 & 1.4 & 1.6 & 1.6 & 1.4 & 1.6 \\
\hline Total & 13.6 & 13.5 & 13.6 & 13.7 & 13.7 & 13.4 & 13.6 \\
\hline
\end{tabular}

a Number of analyses averaged

b Values are oxide weight percent. Numbers within parentheses indicate standard deviations

c Number of cations in an unit cell. Formulae are normalized to 12 tetrahedral and octahedral cations 
Table 2. Average electron microprobe analyses of chlorite mega-grains

\begin{tabular}{|c|c|c|c|c|c|c|c|}
\hline & \multirow{2}{*}{$\begin{array}{l}\text { Mudstone } \\
\text { LG4 }(9)^{\mathrm{a}} \\
\text { (bedding) }\end{array}$} & \multicolumn{6}{|l|}{ Slate } \\
\hline & & $\begin{array}{l}\text { LG20 (9) } \\
\text { (bedding) }\end{array}$ & $\begin{array}{l}\mathrm{RC} \mathrm{(4)} \\
\text { (bedding) }\end{array}$ & $\begin{array}{l}\text { Q1 (5) } \\
\text { (bedding) }\end{array}$ & $\begin{array}{l}\text { Q1 (19) } \\
\text { (cleavage) }\end{array}$ & $\begin{array}{l}\text { Q2 (9) } \\
\text { (bedding) }\end{array}$ & $\begin{array}{l}\mathrm{Q} 2(12) \\
\text { (cleavage) }\end{array}$ \\
\hline $\mathrm{SiO}_{2}$ & $29.3(1.1)^{\mathbf{b}}$ & $25.7(1.4)$ & $27.7(2.3)$ & $24.1(1.0)$ & $25.1(0.7)$ & $25.6(1.0)$ & $25.2(0.8)$ \\
\hline $\mathrm{TiO}_{2}$ & 0.0 & $0.1(0.0)$ & $0.1(0.1)$ & 0.0 & $0.1(0.1)$ & 0.0 & $0.1(0.1)$ \\
\hline $\mathrm{Al}_{2} \stackrel{2}{\mathrm{O}}_{3}$ & $21.4(0.5)$ & $20.9(0.4)$ & $21.5(1.7)$ & $22.3(0.9)$ & $21.6(0.6)$ & $21.9(0.5)$ & $21.1(0.6)$ \\
\hline $\mathrm{FeO}$ & $27.9(0.9)$ & $27.9(1.7)$ & $26.2(2.5)$ & $26.3(1.5)$ & $28.1(1.1)$ & $28.2(0.9)$ & $28.9(0.8)$ \\
\hline $\mathrm{MnO}$ & $0.2(0.1)$ & $0.2(0.1)$ & 0.0 & $0.1(0.1)$ & $0.1(0.1)$ & $0.1(0.0)$ & $0.1(0.1)$ \\
\hline $\mathrm{MgO}$ & $12.3(0.6)$ & $12.0(1.1)$ & $12.3(0.3)$ & $12.6(0.5)$ & $13.3(0.7)$ & $12.7(0.6)$ & $13.1(0.6)$ \\
\hline $\mathrm{CaO}$ & 0.0 & 0.0 & $0.1(0.0)$ & $0.1(0.0)$ & $0.1(0.0)$ & $0.1(0.0)$ & $0.1(0.0)$ \\
\hline $\mathrm{Na}_{2} \mathrm{O}$ & 0.0 & $0.2(0.2)$ & 0.0 & 0.0 & 0.0 & 0.0 & $0.2(0.3))$ \\
\hline $\mathrm{K}_{2} \mathrm{O}$ & $0.1(0.2)$ & $0.3(0.1)$ & $0.1(0.1)$ & $0.2(0.2)$ & $0.1(0.1)$ & $0.2(0.1)$ & $0.1(0.2)$ \\
\hline Total & 85.5 & 87.3 & 88.0 & 85.7 & 88.5 & 88.8 & 88.9 \\
\hline $\mathrm{Si}$ & $5.3^{\mathrm{c}}$ & 5.6 & 6.0 & 5.3 & 5.3 & 5.5 & 5.3 \\
\hline Al IV & 2.7 & 2.4 & 2.1 & 2.7 & 2.7 & 2.5 & 2.7 \\
\hline Al VI & 2.9 & 3.0 & 3.3 & 3.0 & 2.8 & 3.0 & 2.6 \\
\hline $\mathrm{Ti}$ & 0.0 & 0.0 & 0.0 & 0.0 & 0.0 & 0.0 & 0.0 \\
\hline $\mathrm{Fe}$ & 5.1 & 5.0 & 4.7 & 4.8 & 5.0 & 5.0 & 5.1 \\
\hline $\mathrm{Mn}$ & 0.0 & 0.0 & 0.0 & 0.0 & 0.0 & 0.0 & 0.0 \\
\hline $\mathrm{Mg}$ & 4.0 & 3.8 & 3.9 & 4.1 & 4.2 & 4.0 & 4.2 \\
\hline $\mathrm{Ca}$ & 0.0 & 0.1 & 0.0 & 0.0 & 0.0 & 0.0 & 0.0 \\
\hline $\mathrm{Na}$ & 0.0 & 0.1 & 0.0 & 0.0 & 0.0 & 0.0 & 0.1 \\
\hline $\mathrm{K}$ & 0.0 & 0.1 & 0.0 & 0.1 & 0.0 & 0.0 & 0.0 \\
\hline Total & 20.0 & 20.0 & 20.0 & 20.0 & 20.0 & 20.0 & 20.0 \\
\hline
\end{tabular}

a Number of analyses averaged

b Values are oxide weight percent. Standard deviations are within parentheses

c Number of cations in an unit cell. Normalized to 20 total cations

Table 3. AEM analyses ${ }^{\mathrm{a}}$ of illite from mudstone, transitional and slate samples (Number of atoms in one unit-cell)

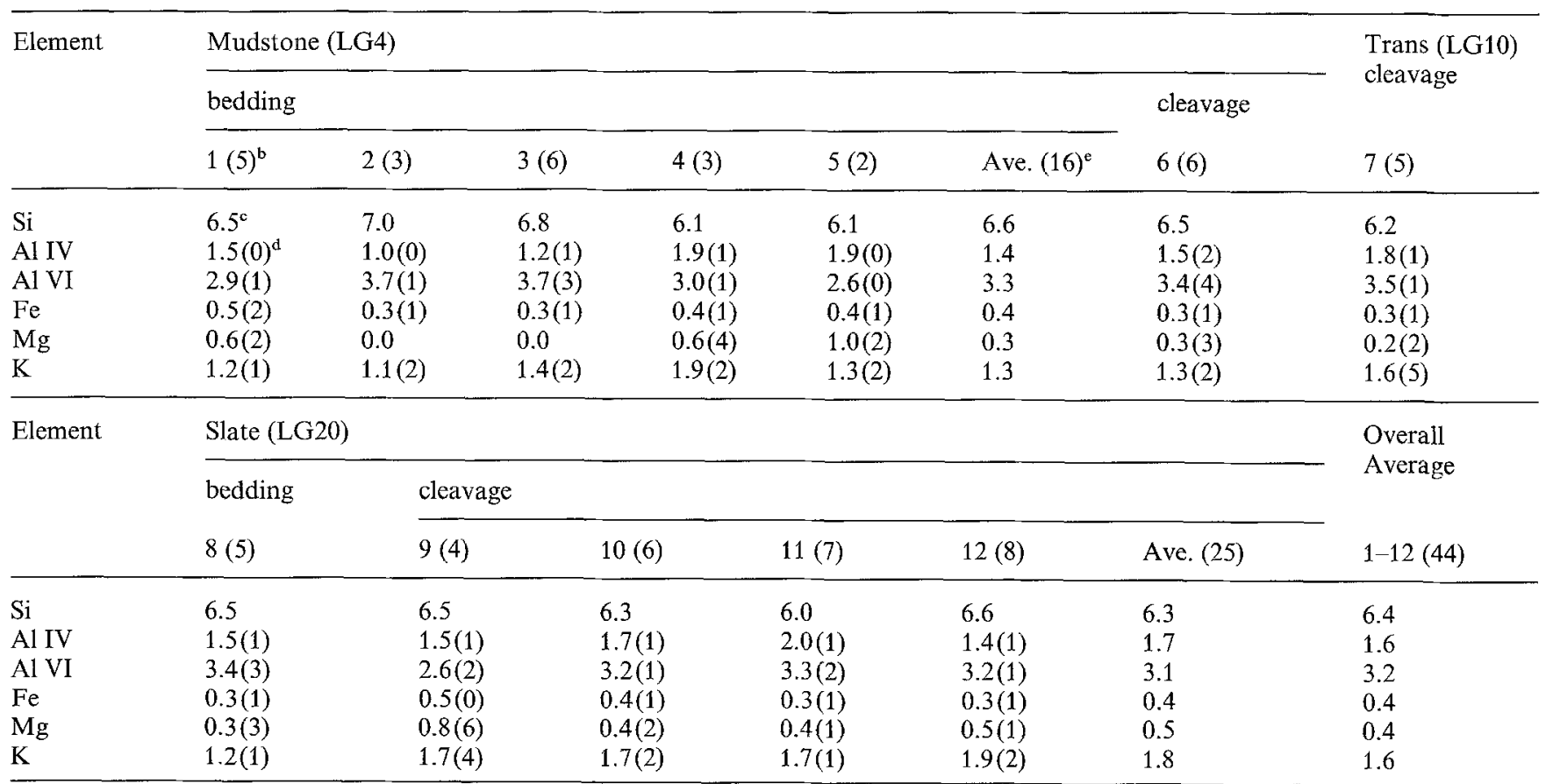

a Analysis conditions are: $100 \mathrm{kV}, 100 \mu \mathrm{a}$, manual CL1 current of $170 \mathrm{ma}$, beam size of approximately 0.1 micron and $35^{\circ}$ sample tilt

b Number of analyses averaged for a single grain

- Values are normalized to 12 total tetrahedral and octahedral cations

d Numbers within parentheses represent standard deviations to the last digit

- Analysis 4 is excluded from calculation for average because of unusually high $\mathrm{K}$ content 
Table 4. AEM Analyses ${ }^{a}$ of chlorite from mudstone, transitional and slate samples. (Number of atoms in one unit-cell, analysis conditions and all other specifications are same as Table 3, unless specified otherwise.)

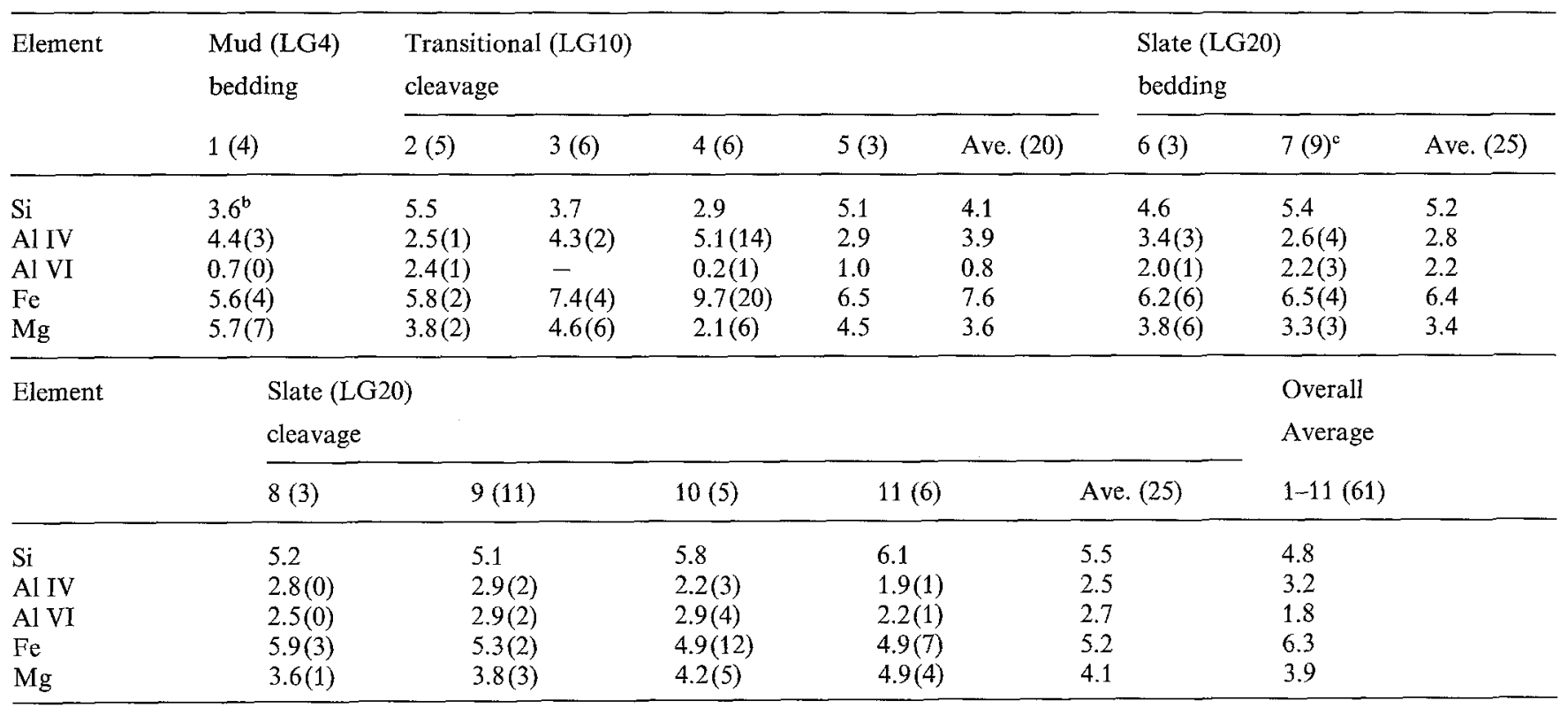

a Many of the chlorite analyzed were interlayered with illite. Illite components in the analyses were subtracted by assuming the illite composition being same as analysis 7 of Table 3

b Values are normalized to 20 total cations

- Point-beam analysis was used

in temperature. In addition, Kanehira and Banno (1960) and Velde (1965) reported the substitution of $\mathrm{Fe}^{3+}$ for $\mathrm{Al}$ up to 25 percent in muscovite.

Because most of the white mica and chlorite crystals are very fine-grained (submicron size) in burial or low temperature metamorphic environments and are intergrown with one another (Holeywell and Tullis 1975; Lewis 1980), the electron microprobe analytical data can easily be contaminated by adjacent crystals and be subject to relatively large errors. Most analytical data for natural illites or muscovites from low grade metamorphic rocks obtained using conventional (wet chemical) techniques (Brammal et al. 1937; Grim et al. 1937; Nagelschmidt and Hicks 1943; Mackenzie et al. 1949; Kerr et al. 1950; Minato and Takano 1952 - referenced in Deer et al. 1962) and electron microprobe techniques (e.g., Guidotti 1973; Brown 1975) show significant amounts of $\mathrm{Fe}$ and $\mathrm{Mg}$ with a wide range of concentrations. However, it is difficult to tell whether these variable $\mathrm{Fe}$ and $\mathrm{Mg}$ contents result from solid solution between muscovite and celadonite or from contamination of adjacent grains. Several qualitative (e.g., Knipe 1979, 1981; White and Johnston 1981; Veblen 1983) and quantitative (Ireland et al. 1983) STEM analyses of illite demonstrate significant phengite components with large variations in concentration between samples. Therefore, it is likely that both solid solution and contamination are included in most analyses with resolution up to the scale detectable using the electron microprobe.

\section{Analytical electron microscopy}

Characterization of phyllosilicates was performed by combining three different techniques; lattice-fringe imaging, selected area electron diffraction and energy dispersive analy- sis (EDA). Stacking sequences of (001) planes of phyllosilicates were directly observed through lattice-fringe imaging in the oriented samples. We did not attempt to obtain structure images; instead, through-focus imaging techniques were employed to obtain the images corresponding to maximum contrast which reflect the true lattice periodicities of 001 layer sequences of most phyllosilicates $\left(\mathrm{d}_{001}\right.$ larger than $7 \AA$; after Allpress et al. 1972; Anderson 1978). The most commonly observed lattice periodicities along $\mathrm{c}^{*}$ are 10 , 14 and $7 \AA$. The orientation of $\mathrm{c}^{*}$ and magnitude of layer spacings are verified by the electron diffraction pattern for ool reflections from selected areas. Selected areas of phyllosilicate grains, having first been characterized by TEM techniques, were analyzed with AEM. Owing to the fine-grained nature of phyllosilicates in the sample, the electron beam was rastered over a small analysis area $(800 \times 800 \AA)$. Gotthard adularia served as a standard for $\mathrm{Al}$ and $\mathrm{K}$ and Marjalahti olivine for $\mathrm{Mg}$ and $\mathrm{Fe}$ in the STEM analyses. K exhibited much lower and variable intensity ratios than expected for the minerals analyzed, probably due to diffusion caused by the electron beam (Knipe 1979; Craw 1981). Special care was taken to obtain accurate analyses for K (Lee and Peacor 1985b).

Tables 3 and 4 show AEM analyses of illite and chlorite in the samples from the Lehigh Gap outcrop. The analyses in general demonstrate a large variation in composition for both illite and chlorite not only between different samples but also within samples (Tables 3 and 4; Figs. 2 through 4). This probably is inherited from heterogeneities in grains of the original sediment and may reflect the disequilibrium conditions typical of such a low temperature environment. Nevertheless, average compositions of each sample show some significant trends concomitant with the transition from mudstone to slate. Average data from AEM analyses 


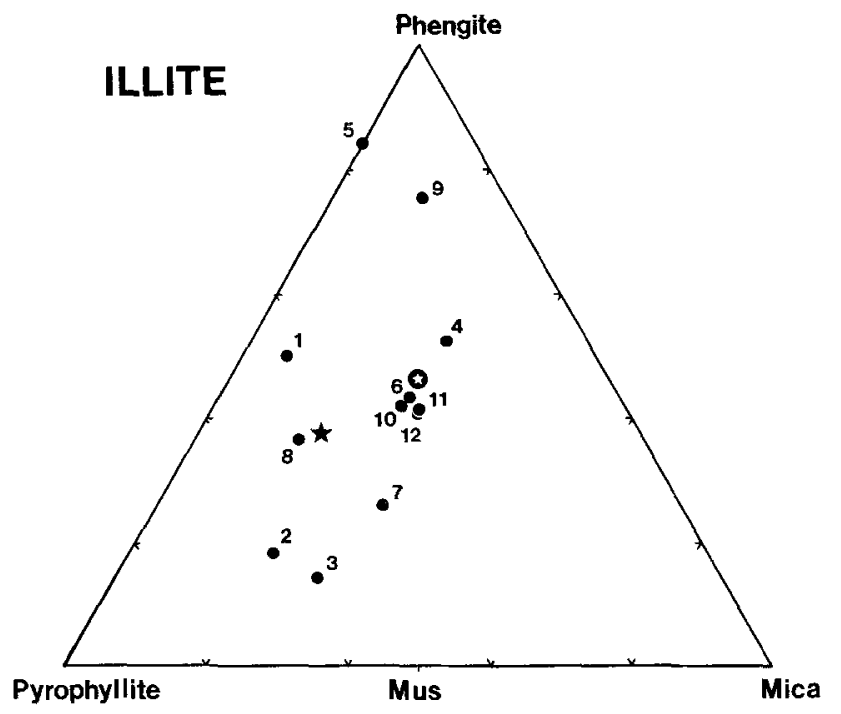

Fig. 2. A triangular plot of illite compositions given in Table 2 in the system: phengite, $\mathrm{K}_{2}(\mathrm{Fe}, \mathrm{Mg})_{2} \mathrm{Al}_{2} \mathrm{Si}_{8} \mathrm{O}_{20}(\mathrm{OH})_{4}$ - theoretical mica, $\mathrm{K}_{4} \mathrm{Al}_{4}\left(\mathrm{Si}_{4} \mathrm{Al}_{4}\right) \mathrm{O}_{20}(\mathrm{OH})_{4}$ - pyrophyllite, $\mathrm{Al}_{4} \mathrm{Si}_{8} \mathrm{O}_{20}(\mathrm{OH})_{4}$. The proportions of the three components are calculated following the method of Stephens et al. (1979). The number of each plot corresponds to the analysis number in Table 2. The black star and the white star in a black circle correspond to the average illite compositions in bedding orientation of mudstone and in cleavage orientation of slate, respectively

of illite and chlorite (Tables 3 and 4) are very similar, in general, to those of the microprobe analyses (Tables 1 and 2 ). This suggests that electron microprobe analyses, if carefully done, could also reflect true compositions despite the contamination problem.

Comparison of the average illite composition of mudstone in the bedding orientation and that of slate in the cleaveage orientation (Table 3 and Fig. 2) shows that there is an increase of $\mathrm{K}$ and $\mathrm{Al}$ and decrease of $\mathrm{Si}$ parallel to the transition. This change is also consistent with the transformation of illite to muscovite as observed by X-ray diffraction (Lewis 1980; Lee et al. 1982a, 1985 b) in that illite in general has less $\mathrm{K}$ and $\mathrm{Al}$ than muscovite. The $\mathrm{Fe}$ content remains the same and the apparent increase of $\mathrm{Mg}$ is not significant considering its relatively large error (Table 3 ).

Velde (1977b) plotted compositions of 19 naturally occurring illites in $M R^{3}-2 R^{3}-3 R^{2}$ coordinates where $M$ represents monovalent alkali cations (mainly $\mathrm{K}$ ), $\mathrm{R}^{3}$ trivalent cations ( $\mathrm{Al}$ and $\mathrm{Fe}^{3+}$ ) and $\mathrm{R}^{2}$ divalent cations $(\mathrm{Mg}$ and $\mathrm{Fe}^{2+}$ ). The plot of illite compositions presented in Table 3 (AEM analyses) is superimposed on Velde's illite composition range (Fig. 3) and shows a larger deviation from the stoichiometric muscovite. This may indicate that samples used in this study range from the lower grade of diagenetic sequences than those in Velde's.

The analyses of chlorite (Table 4) show a wide range of composition. The plot of chlorite composition in Fig. 4 exhibits a much larger scatter than the data reported by Knipe (1981). Although Frey (1978) and Knipe (1981) observed a decrease in Fe content in chlorite during progressive metamorphism, our data show no definite trend concomitant with the mudstone to slate transition (Fig. 4). Some other variable than temperature must, therefore, have a significant effect on Fe content of chlorite and, as described above, also on $\mathrm{Fe}$ and $\mathrm{Mg}$ contents of illite.

Analyses of chlorite often include significant amounts of $\mathrm{K}$. Local scale interlayering of illite within chlorite is assumed because this type of interlayering at an individual layer level is commonly observed as noted by Lee and Peacor (1983) and as we show below, in this paper. At this small scale, it may not be directly imaged by TEM mainly due to rapid damage of the illite structure by the electron beam. In this case, illite components were sub-tracted from the chlorite analyses as described by Lee and Peacor (1985a). Most of the chlorite analyses fall in the range of ripidolite composition (Foster 1962) and this is consistent with Lewis' (1980) analyses of the large phyllosilicate grains using electron microprobe analysis. Although not plotted in Fig. 2, 3 and 4, compositions of illite and chlorite obtained by electron microprobe analyses fall in similar but much smaller areas of these diagrams than those obtained by AEM analyses.

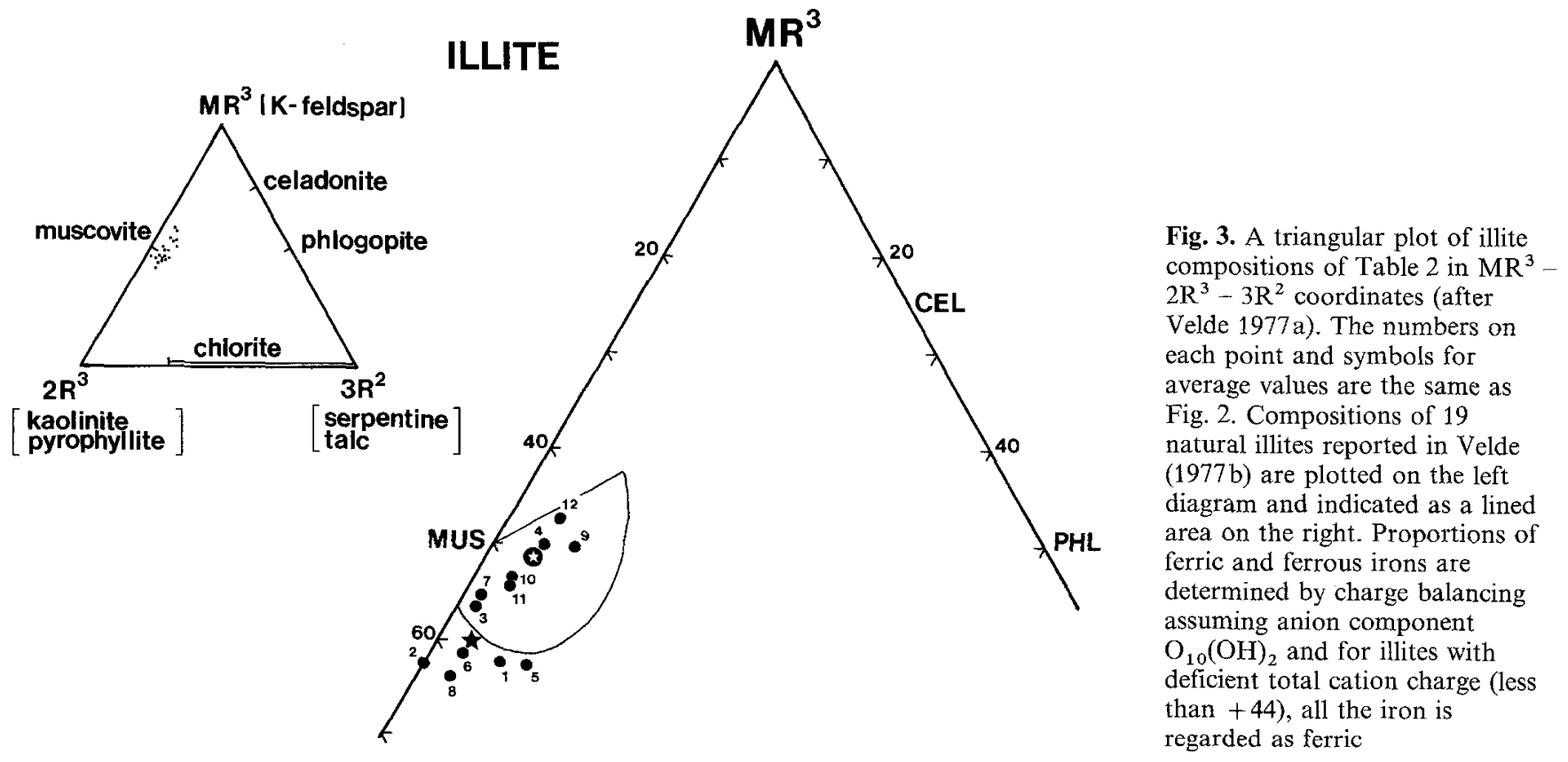




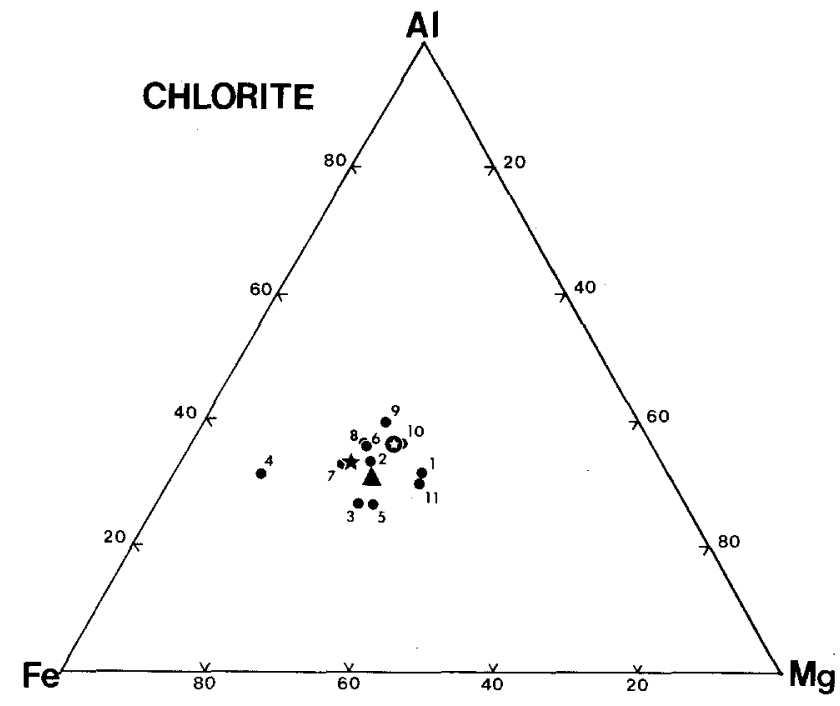

Fig. 4. Chlorite compositions presented in Table 3 are plotted on an AFM diagram (molecular ratios). The number on each point corresponds to the analysis number in Table 3 . The triangle, the black star, and the white star in the black circle represent average chlorite compositions in cleavage orientation of transitional sample, in bedding orientation of slate, and in cleavage orientation of slate, respectively

\section{Transmission electron microscopy}

\section{Mudstone sample}

A lattice fringe image of a phyllosilicate grain from the mudstone reveals a packet of $14 \AA$ chlorite interleaved within the dominant $10 \AA$ illite (Fig. 1). The illite layers in this image are unusually well-developed as compared with the average illite of the mudstone which generally exhibits edge dislocations and other imperfections. The mottled appearance of the illite is characteristic only of that phase. In all subsequent images the illite may be identified by this feature, vis-a-vis chlorite. The chlorite and illite layers are subparallel and the misfit at the boundary is accomodated by layer terminations. The image is unfortunately incomplete and the lack of contrast in some areas prevents a complete analysis of the boundary, which as a result of the layer terminations, is apparently only semi-coherent.

Another example of a typical phyllosilicate of the mudstone shows that packets of illite and chlorite layers are subparallel to one another (Fig. 5A). The boundaries between packets are small angle grain boundary-like features with layer terminations each of which could be characterized as an edge dislocation. The phyllosilicate layers shown in Fig. 5A are approximately normal to the bedding plane of the mudstone. A lattice fringe image at a higher resolution shows a relatively unusual but significant relation between 10 and $14 \AA$ layers (Fig. 5B). All layers shown are parallel or nearly so and are thus part of the same phyllosilicate crystal. There are relatively thick units of only illite which, within the figure, are over $200 \AA$ thick. In addition there is one unit consisting of more than 10 consecutive $14 \AA$ chlorite layers. Moreover, there is also considerable ordered $1: 1,24 \AA$ chlorite/illite within which stacking disorder occurs giving rise to random illite/chlorite interlayering. Such ordered 1:1 mixed layer chlorite/illite has been separately described by Lee and Peacor (1985a) where
AEM data confirm that the chlorite is trioctahedral and the illite dioctahedral.

\section{Transitional sample}

As in Fig. 5B, a lattice fringe image of a typical phyllosilicate grain which is transitional from mudstone to slate demonstrates well defined packets of illite and chlorite layers. They are subparallel to one another and have edge dislocation-like layer terminations at the boundaries (Fig. 6A). However, there is frequent and random interlayering of 10 and $14 \AA$ units, with no regularly repeating $24 \AA$ units. A portion of a grain from a transitional sample shows a rather unusual but significant occurrence of a well ordered $24 \AA$, 1:1 chlorite/illite mixed-layer at a higher resolution (Fig. 6B). Although such a regular repeat is unusual, the interlayering of 10 and $14 \AA$ layers in a random to semiregular way is common in transitional samples.

A higher resolution lattice fringe image of a crystal from a transitional sample reveals, in addition to illite and chlorite, $7 \AA$-layers in direct association with $14 \AA$ chlorite layers (Fig. 7). Indeed, 7, 10 and $14 \AA$ units may be transitional to one another along individual layers. Such complex inter- and intralayer transitions and mixed layers were described by Lee and Peacor (1983). The $7 \AA$ phase is Fe and $\mathrm{Mg}$-rich. It is therefore a trioctahedral phase (serpentine type structure) which is best referred to as berthierine.

The structure layers of regularly and randomly interlayered illite and chlorite (Figs. 6 and 7) occur only parallel to the slaty cleavage plane of the nearby slates. The specimens, however, show abundant grains with orientations parallel to bedding. Such grains are similar to those shown in Fig. 1 . The amount of $14 \AA$ chlorite within the randomly interlayered grains in Figs. 6 and 7 appears to be greater than that in Fig. 5B. This suggests that the proportion of chlorite interlayered with illite increases as the transition from mudstone to slate proceeds.

\section{Slate sample}

A packet of illite is interleaved with a large grain of chlorite as observed in a slate sample from the Lehigh Gap outcrop (Fig. 8). There are no detectable randomly interlayered chlorite-illite units in this image or in any images from the slate, in general. However, the interface between chlorite and illite contains some unusual features. Here, layers generally have $14 \AA$ periodicity but are imperfect and show mixed-layer stacking disorder; three consecutive units of $7 \AA$ layers occur in at least two places within the $14 \AA$ layers. The selected area electron diffraction pattern of $00 \mathrm{l}$ reflections in the inset also shows well defined $10 \AA$ illite, $14 \AA$ chlorite and diffuseness along $\mathrm{c}^{*}$ caused in part by the mixed layering in that area. Structures similar to the $7 \AA$ layers which are found within $14 \AA$ layers in Fig. 8 are also described in Veblen (1983) and Ahn et al. (1983) and apparently have a serpentine-type structure and a composition similar to chlorite as reported by Lee and Peacor (1983).

Images of typical phyllosilicate grains of the slate sample from a quarry exhibit layers of illite and chlorite both of which occur as well-developed packets of several thousand Ångstroms thick (Figs. 9A and 9B). The individual packets may still exhibit subparallel boundaries as in Fig. 9A, but highly perfect units also occur in parallel orien- 

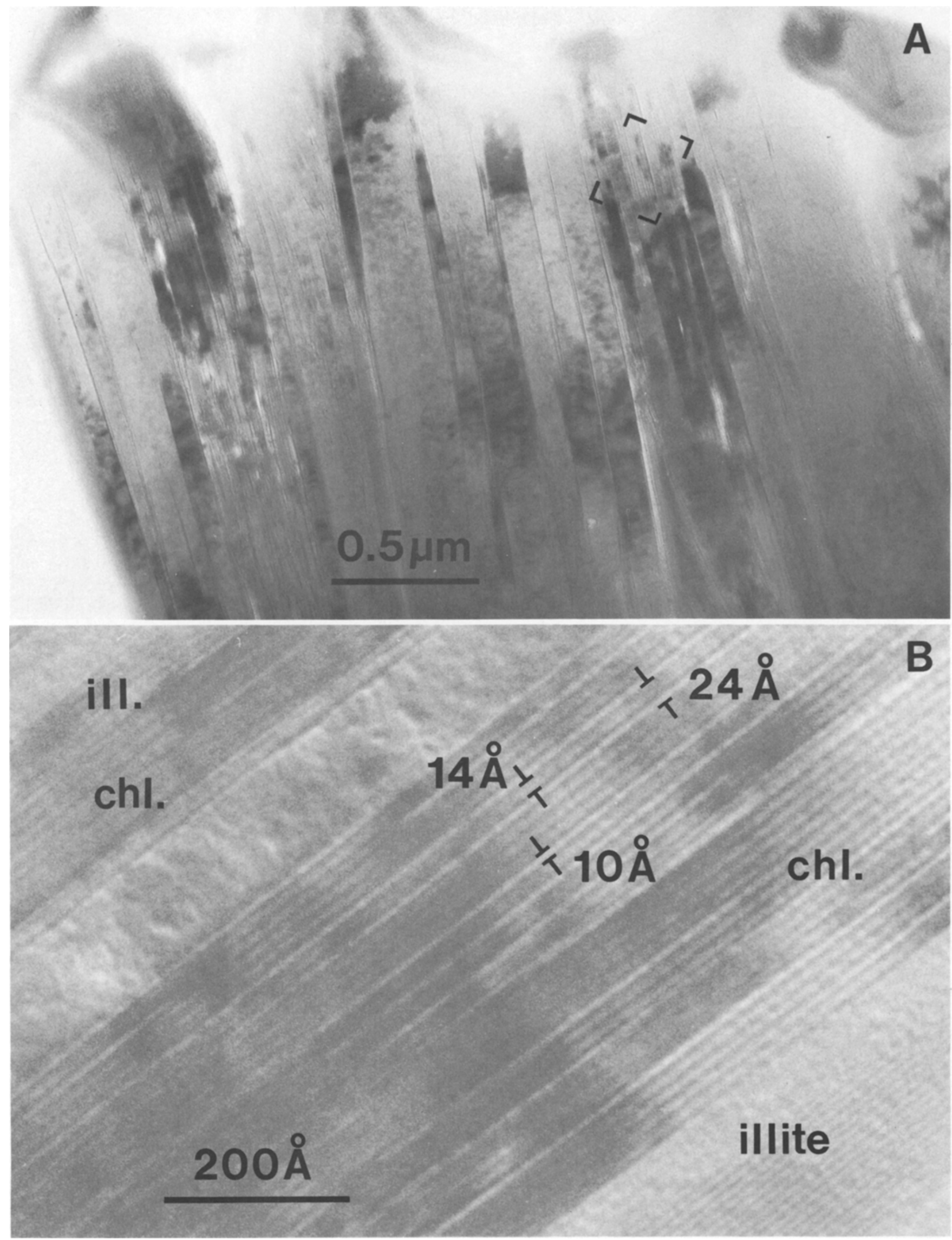

Fig. 5A, B. A A portion of a typical phyllosilicate grain containing subparallel packets of illite and chlorite layers in the mudstone sample. B A lattice fringe image showing an interlayered relationship between $10 \AA$ illite and $14 \AA$ chlorite from the same area as Fig. $5 \mathrm{~A}$ (The enlarged area is bracketed) 


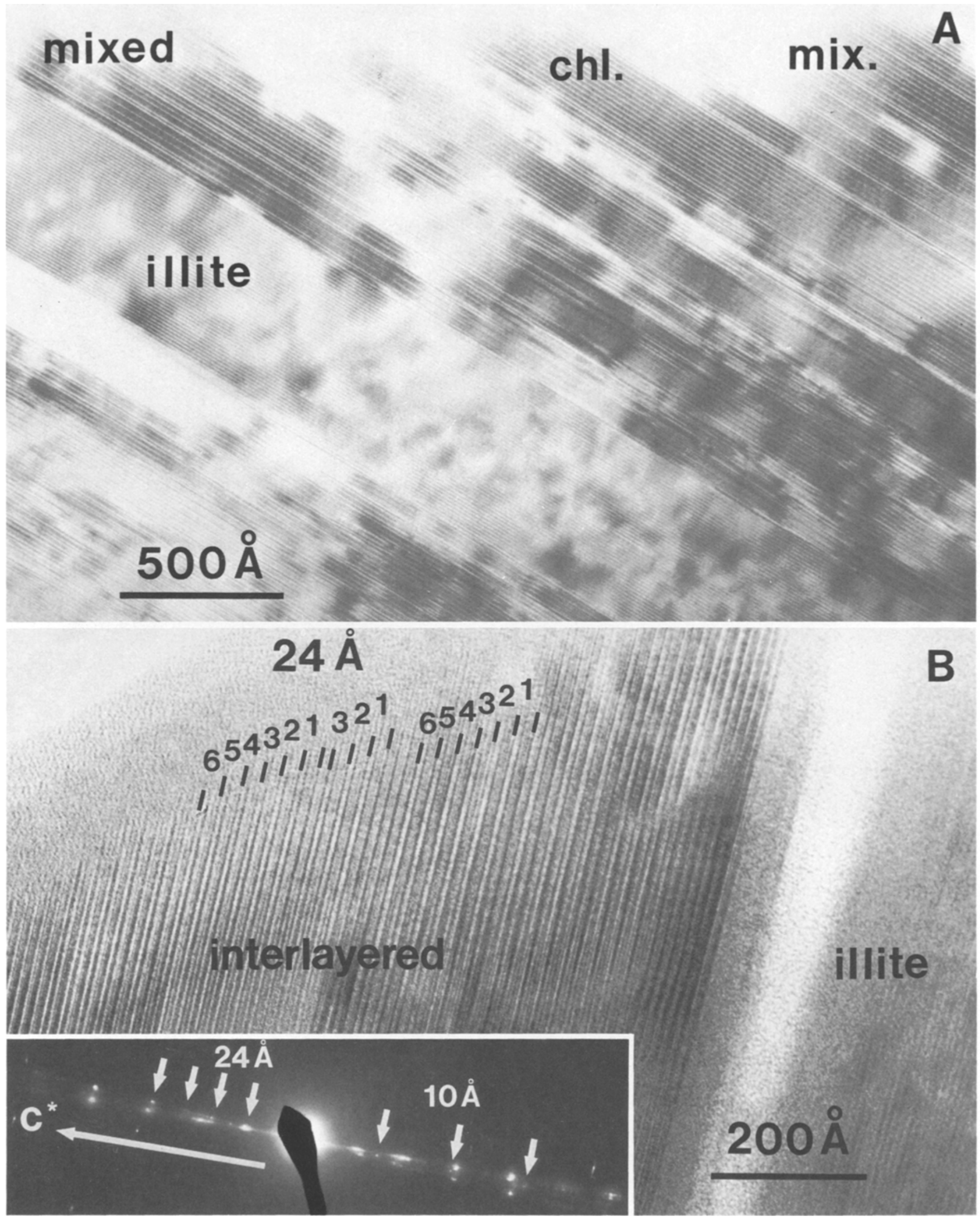

Fig. 6A, B. A A lattice fringe image of a typical phyllosilicate grain from a sample transitional to slate. There are areas of randomly interlayered illite and chlorite as well as packets of pure illite and chlorite. B A lattice fringe image of an area from the same sample as Fig. 6A. Illite and chlorite layers alternate regularly to produce a phase with ordered $24 \AA$ periodicity. The inset diffraction pattern shows the $00 l$ reflections of the ordered 1:1 phase with streaking along $\mathrm{c}^{*}$ which is due in part to random interlayering between ilite and chlorite 


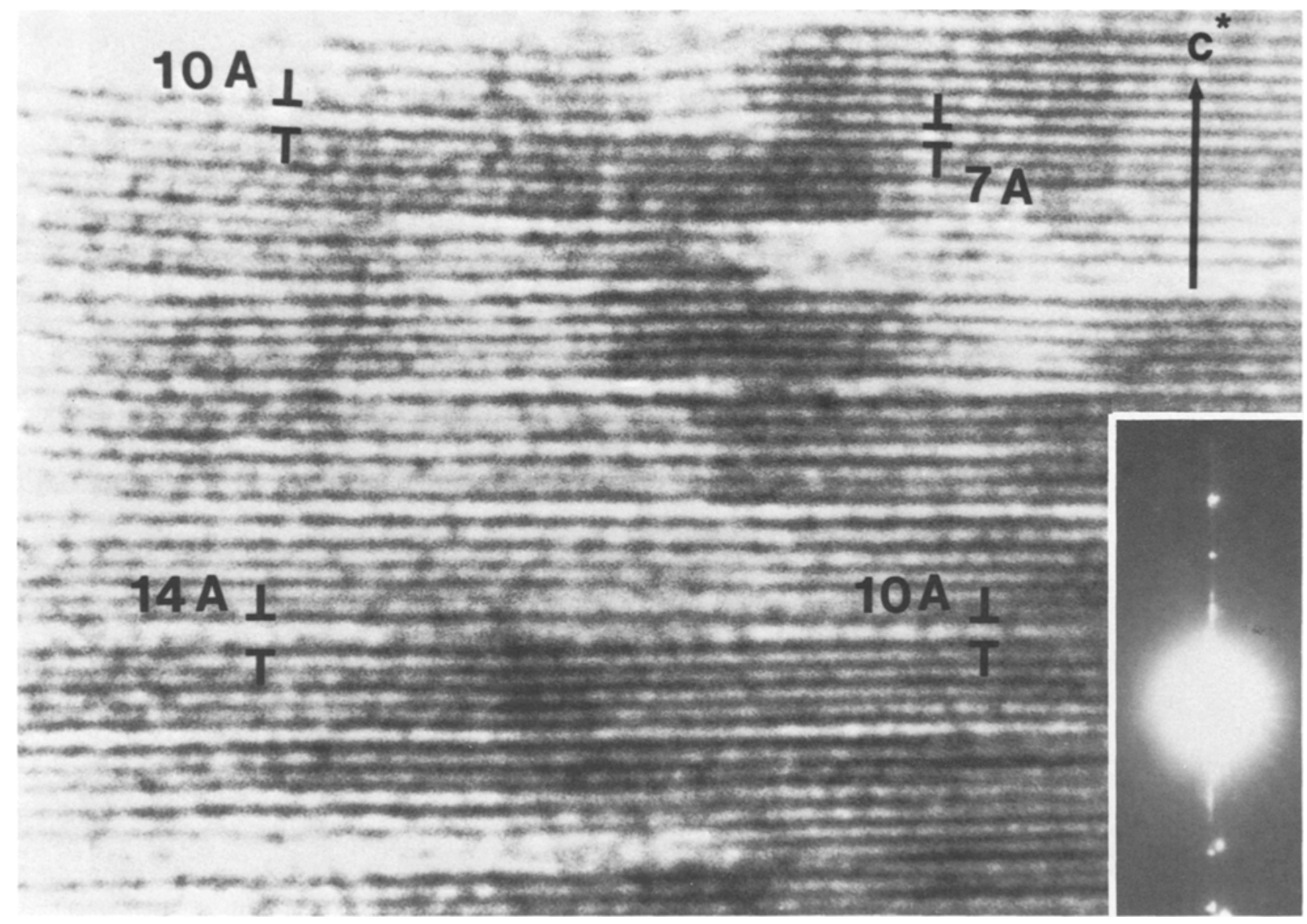

Fig. 7. A higher resulution lattice fringe image showing intralayer transitions between $10 \AA$ illite, $14 \AA$ chlorite and $7 \AA$ berthierine (see Lee and Peacor 1983). The sample is intermediate between mudstone and slate (Courtesy of Macmillan Journals Ltd.)

tation with coherent boundaries as shown in Fig. 9B. Such highly perfect grains of the slate are usually 2-layer polytypes.

\section{Summary and discussion}

The general sequence of changes observed by TEM and AEM involving chlorite/illite interlayering can be characterized by the following three stages: (1) Mudstone - Imperfect grains with high densities of dislocations and other defects consist of subparallel packets of layers of illite and chlorite with incorherent boundaries. Such packets may be several hundred Angstroms in thickness. At the TEM level, illite is the predominant phase and grains are primarily oriented parallel to bedding (Lee et al. 1985b). (2) Transitional sample - Grains parallel to bedding are the same as those of the mudstone. Grains parallel to the cleavage commonly consist, in part, of randomly or regularly interlayered 10 and $14 \AA$ layers. Where packets of homogeneous illite or chlorite layers occur, they are only a few hundred Ångstroms thick. (3) Slate - The majority of grains are relatively perfect (defect-free) intergrowths of packets of $14 \AA$ chlorite layers and $10 \AA$ dioctahedral mica layers. Packets of either illite or chlorite may be several thousand Ångstroms in thickness. Boundaries between packets are semi-coherent. The mica is dominantly a two-layer polytype. Grains show a marked preference for an orientation parallel to the slaty cleavage, which is in turn approximately normal to the bedding.

The $10 \AA$ dioctahedral phase shows, on average, regular changes from mudstone to slate as shown by data presented above and by Lee et al. (1985b). (1) The Si content decreases, and the $\mathrm{Al}$ and $\mathrm{K}$ contents increase, such that the $10 \AA$ phase in the slate is near stoichiometric muscovite in composition. (2) Most illite of the mudstone is a 1-layer polytype (1M) while 2-layer (2M?) sequences are the common stacking unit in the slate. (3) Illite in the mudstone has a relatively high density of layer terminations, edge dislocations and other imperfections, but the mica of the slate has a relatively perfect structure. Lee et al. (1985b) interpret the progressive transitions in the $10 \AA$ phases as a regular transition from a metastable, non-equilibrium illite toward a stable, stoichiometric muscovite. The activation energy is provided by strain and temperature accompanying deformation, and the degree of transition is controlled by kinetic factors. The highly imperfect nature of the grains of the mudstones is an important factor in that this represents a high energy state which acts to promote reaction. The transition appears to occur only on a local basis with diffusion occurring only over distances as large as microns; i.e., the transition is apparently largely one involving a locally closed system.

There are several questions raised by our results from these samples. The first question concerns the chlorite/illite interlayering in the mudstone. Hower et al. (1976) proposed 


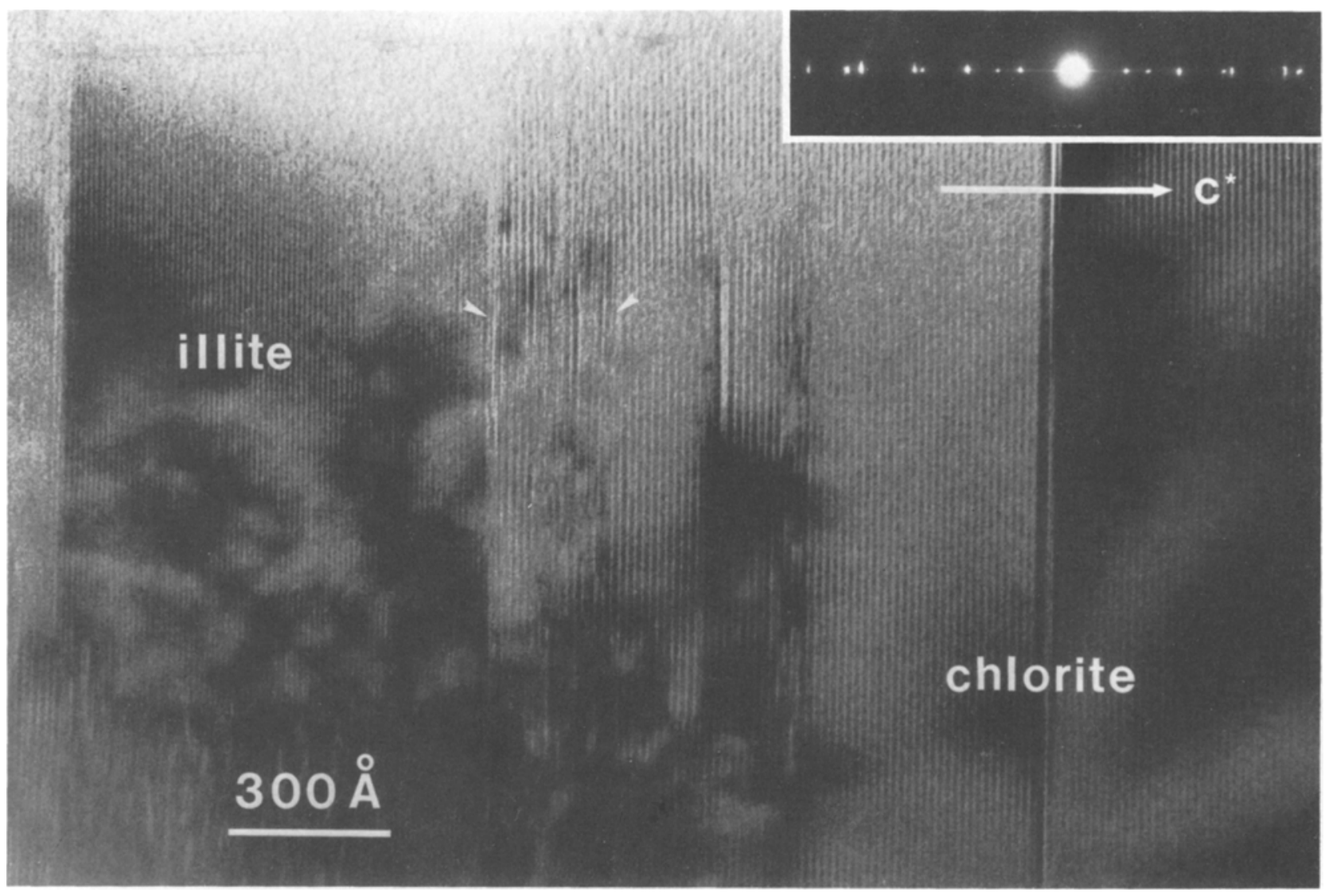

Fig. 8. A type of illite-chlorite interlayering found in slate. $7 \AA$ serpentine-structure layers are interlayered with relatively imperfect $14 \AA$ chlorite layers which are in turn located between packets of well defined relatively defect-free illite and chlorite layers. The inset electron diffraction pattern shows diffuseness parallel to $c^{*}$ as well as sharp illite and chlorite reflections

that chlorite which appears at depth in a burial metamorphic sequence may be derived through transformation of smectite to illite. Ahn et al. (1983) have verified the increasing proportion of chlorite intergrown with illite and/or with mixed layer illite/smectite in the same Gulf Coast sequence studied by Hower et al. (1976). Indeed, the chlorite frequently is randomly interlayered with trioctahedral $7 \AA$ layers, or interlayered as packets of 7 and $14 \AA$ layers with the former showing complex polytypism. The original smectite has a considerable $\mathrm{Mg}$, Fe component as compared with the illite to which it transforms. It is this trioctahedral component which must result in the 7 and $14 \AA$ trioctahedral layers. Ahn et al. (1983) show that the $7 \AA$ trioctahedral phase transforms to chlorite with further diagenesis. The result is packets of $14 \AA$ chlorite layers within dominant $10 \AA$ illite.

As the state of the mudstone at Lehigh Gap is presumably derived by burial metamorphism (diagenesis) of Gulf Coast-like sediment, it is reasonable to assume that the illite/chlorite interlayered texture of the mudstone at Lehigh Gap is derived in the same manner. Indeed, Wintsch (1978) originally proposed that the deepest Gulf Coast sediments studied by Hower et al. (1976) were equivalent in state of diagenesis/metamorphism to the least transformed mudstones at Lehigh Gap. Additional data for such continuity has been presented by Lee et al. (1982a, 1984, 1985a) and Ahn et al. (1983).

The second question concerns the mechanism for conversion of smectite to grains consisting of parallel packets of illite and chlorite. Ahn et al. (1983) postulate a diffusioncontrolled reaction in which original smectite structure layers are in part preserved. If such a part solid-state, part solution-recrystallization mechanism is valid, then the phyllosilicate grains shown in Fig. 4 and 5 have been directly converted from smectite which once occupied that same space.

The interlayered illite/chlorite of the transitional samples is of two types: (1) Grains which are dominantly parallel to the bedding plane and similar to those of the mudstone. Images of these grains were not shown because they are so similar to those of the mudstone. (2) Grains which show complex mixed layering of illite and chlorite. A layer sequence may consist of: a. layers only of illite or of chlorite, giving rise to a packet of one-phase layers, $b$. regular mixed-layer 1:1 chlorite/illite, and/or c. randomly interlayered chlorite/illite. These grains have an orientation which is primarily parallel to the plane of developing slaty cleavage.

Lee et al. $(1983 ; 1985 \mathrm{~b})$ have verified the conclusions of Holeywell and Tullis (1975), Lewis (1980), and Wintsch (1978), that slaty cleavage at Lehigh Gap is developed through a solution-recrystallization mechanism. The complex interlayered 10 and $14 \AA$ material in the mudstone sample thus appears to represent the initial phase of crystallization of the slaty cleavage component from the solution of illite, chlorite and possibly illite/smectite mixed-layer grains parallel to bedding. At this stage, the transition must not involve solid state mechanisms, at least not in large 


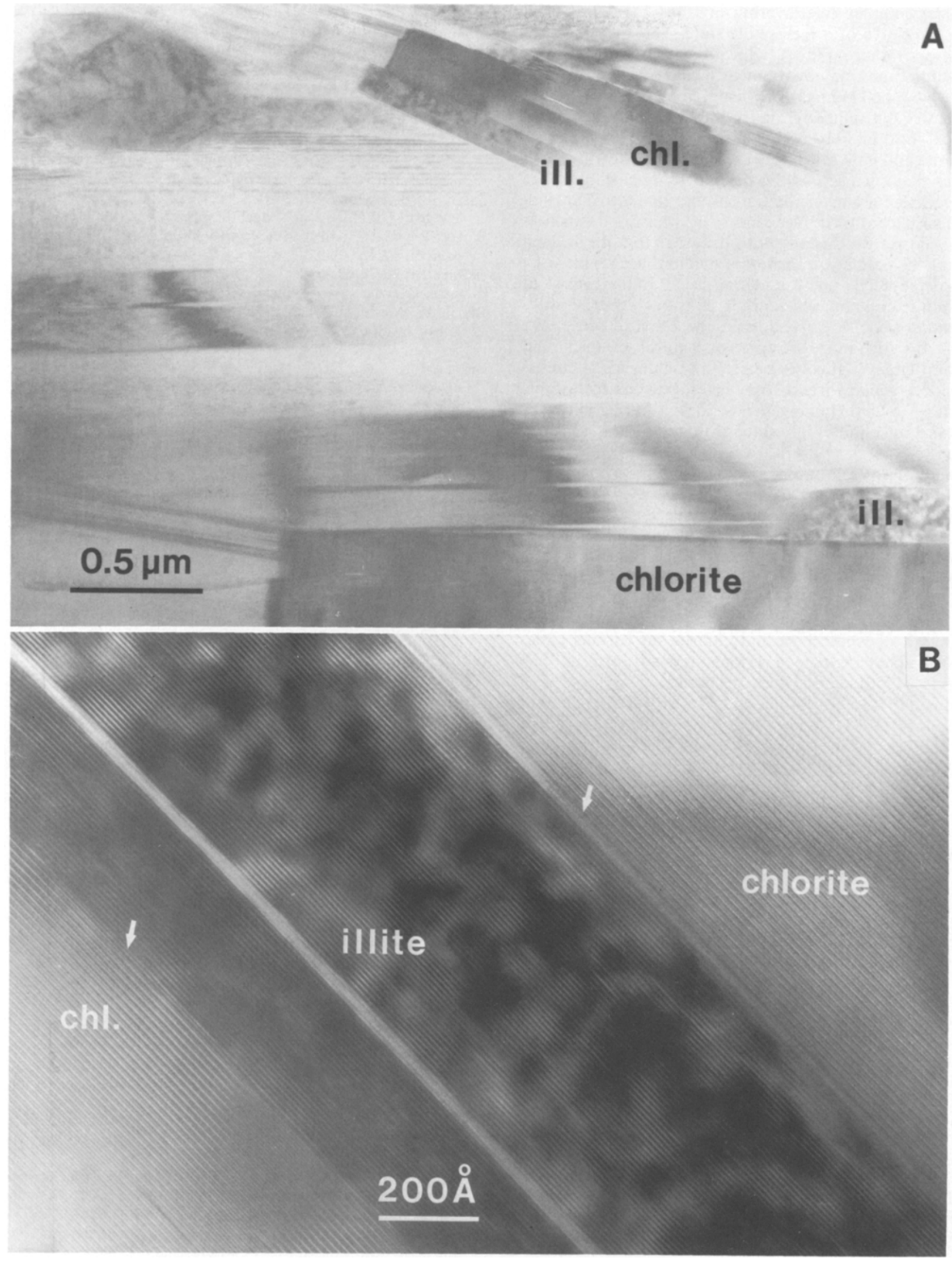

Fig. 9A, B. A A TEM image of typical phyllosilicate grains of a slate sample from a quarry. B A lattice fringe image of highly perfect chlorite and illite interleaved as packets of layers 
part. The complex interlayering in transitional phases is clearly indicative of a metastable state. This may have resulted from rather rapid crystallization at low temperatures during diagenesis, an environment which is generally characterized by such high entropy features.

The well crystallized grains of the slate only rarely show complex, local interlayering. The thick, alternating packets of chlorite and illite/muscovite are relatively defect-free. We propose that such grains are derived by annealing of the more complex grains of the transitional samples. The data are consistent with a mechanism of transition which is partly solid-state diffusion-controlled, such that the original layers of the complex transitional material are replaced by well-ordered single-phase material. Such grains consist of single-phase domains which are large enough to be considered equilibrium single phases in the classical sense. We propose that the entire sequence of textural, chemical and structural changes involving illites and chlorites is consistent with a general trend from heterogeneous metastable structures toward homogeneous, defect-free grains approaching an equilibrium state with their local environment.

The pervasive nature of the intergrowths in phyllosilicate grains at Lehigh Gap, in combination with these other observations, implies that chlorite-illite/muscovite intergrowths at the sub-optical scale may be very common. Assuming that the illite and chlorite of the mudstone were derived from precursor smectite, and that this is a common mode of genesis, such intergrowths may be the rule rather than the exception in shales, mudstones and slates. The intergrowth of white mica and chlorite on various scales has been noted in many previous studies: Sorby (1853), Hoeppner (1956), Voll (1960), Attewell and Taylor (1969), Williams (1972), Holeywell and Tullis (1975), Beutner (1978), Ray (1978), White and Knipe (1978), Page and Wenk (1979), Knipe (1981), Weber (1981), Craig et al. (1982), Woodland (1982) and van der Pluijm and KaarsSijpestejn (1984). As shown in our micrographs, such interlayer relations may commonly occur at a scale down to single layers, and most certainly below the scale of optical resolution or electron beam-sample interaction in the electron microprobe. Indeed, even AEM techniques cannot resolve single phases in some cases. Therefore, chemical analyses of such crystals will result in serious contamination problems as indicated in the previous section. Veblen (1983) has also pointed to these implications for chemical data. We would also not only emphasize caution in interpreting analyses of chlorites and white micas but emphasize that such interlayer relations among all phyllosilicates in terms of their tri- und dioctahedral components are more common than generally realized and chemical analyses should be interpreted accordingly.

Acknowledgements. Lawrence Allard and members of the University of Michigan Electron Microbeam Analysis Laboratory, are thanked for their help. The manuscript was reviewed by Eric Essene of the Department of Geological Sciences, The University of Michigan. This study was supported by NSF grant EAR-8107529 to Donald R. Peacor.

\section{References}

Ahn JH, Lee JH, Peacor DR (1983) Mineralogical and textural transitions in phyllosilicates during burial diagenesis of Gulf Coast shales. Geol Soc Am Abstr with Progr 15(6):512
Allard LF, Blake DF (1982) The practice of modifying an analytical electron microscope to produce clean X-ray spectra. In: Heinrich KFJ (ed) Microbeam Analysis - 1982, San Francisco Press, San Francisco, pp 8-19

Allpress JG, Hewat EA, Moodie AF, Sanders JV (1972) n-beam lattice images. I. experimental and computed images from $\mathrm{W}_{4} \mathrm{Nb}_{26} \mathrm{O}_{77}$. Acta Crystallogr A28:528-536

Anderson JS (1978) Lattice imaging by high resolution electron microscopy. The role of high resolution electron microscopy in solid state chemistry. Proc Indian Acad Sci 87 A(10):295-329

Attewell PB, Taylor RK (1969) A microtextural interpretation of a Welsh slate. Int J Rock Mech Min Sci 6:423-438

Bailey SW (1982) Nomenclature for regular interstratifications. Am Mineral 67:394-398

Beutner EC (1978) Slaty cleavage and related strain in Martinsburg slate, Delaware Water Gap, New Jersey. Am J Sci 278:1-23

Blake DF, Allard LF, Peacor DR, Bigelow WC (1980) Ultraclean X-ray spectra in the JEOL JEM-100 CX. Proc Electr Micros Soc Am 38:136-137

Brammal F, Leech JGC, Bannister FA (1937) The paragenesis of cookeite and hydromuscovite associated with gold at Ogofau, Carmarthenshire. Mineral Mag 24:507

Brown EH (1957) A petrologic grid for reactions producing biotite and other Al-Fe-Mg silicates in the greenschist facies. J Petrol $16: 258-271$

Cliff G, Lorimer GW (1975) The quantitative analysis of thin specimens. J Micros 103:203-207

Craig J, Fitches WR, Maltman AJ (1982) Chlorite-mica stacks in low-strain rocks from central Wales. Geol Mag 119:243-256

Craw D (1981) Oxidation and microprobe-induced potassium mobility in iron-bearing phyllosilicates from the Otago schists, New Zealand. Lithos 14:49-57

Craw D, Coombs DS, Kawachi Y (1982) Interlayered biotite-kaolin and other altered biotites, and their relevance to the biotite isograd in eastern Otago, New Zealand. Mineral Mag 45:79-85

Deer WA, Howie RA, Zussman J (1962) Rock forming minerals vol 3, sheet silicates. Longmans, Green and Co. LTD, London 270

Epstein JB, Epstein AG (1969) Geology of the Valley and Ridge province between Delaware Water Gap and Lehigh Gap, Pennsylvania. In: Subitzky Seymur (ed) Geology of selected areas in New Jersey and eastern Pennsylvania and guidebook of excursions, New Brunswick, New Jersey, Rutgers Univ Press, $132-205$

Foster MD (1962) Interpretation of the composition and a classification of the chlorite. USGS Prof Pap 414-A:1-33

Frey M (1978) Progressive low grade metamorphism of a black shale formation, Central Swiss Alps. J Petrol 19:93-135

Goldstein JI, Costley JL, Lorimer GW, Reed SJB (1977) Quantitative X-ray microanalysis in the electron microscope. SEM Inc 1977. In: Johari O (ed) IIT Research Inst Chicago Illinois $1: 315-324$

Grim RE, Bray RH, Bradley WF (1937) The mica in argillaceous sediments. Am Mineral 22:813

Guidotti CV (1973) Compositional variation of muscovite as a function of metamorphic grade and assemblage in metapelites from NW. Maine. Contrib Mineral Petrol 42:33-42

Hoeppener R (1956) Zum Problem der Bruchbildung, Schieferung und Faltung. Geol Rundsch 45:247-283

Holeywell RC, Tullis TE (1975) Mineral reorientation and slaty cleavage in the Martinsburg Formation, Lehigh Gap, Pennsylvania. Geol Soc Am Bull 86:1296-1304

Hower J, Eslinger EV, Hower ME, Perry ED (1976) Mechanism of burial metamorphism of argillaceous sediment: 1. Mineralogical and chemical evidence. Geol Soc Am Bull 87:725-737

Iijima S, Zhu J (1982) Electron microscopy of a muscovite-biotite interface. Am Mineral 67:1195-1205

Ireland BJ, Curtis CD, Whiteman JA (1983) Compositional variation within some glauconites and illites and implications for their stability and origins. Sedimentology 30:769-786

Isaacs AM, Brown PE, Valley JW, Essene EJ, Peacor DR (1981) 
An analytical electron microscopic study of a pyroxene-amphibole intergrowth. Contrib Mineral Petrol 77:115-120

Kanehira K, Banno S (1960) Ferriphengite and aegirine jadeite from the Iunori district. Geol Soc J J 66:654-659

Kerr PF, Hamilton PK, Pill RJ (1950) Analytical data on reference clay materials. Prelim Report (7), Reference clay minerals. Am Petrol Inst Res Proj 49: Columbia Univ New York 38

Klein C (1974) Greenalite, stilpnomelane, minnesotaite, crocidolite and carbonates in very low grade metamorphic Precambrian iron-formation. Can Mineral 12:475-498

Knipe RJ (1979) Chemical analyses during slaty cleavage development. Bull Mineral 102:206-210

Knipe RJ (1981) The interaction of deformation and metamorphism in slates. Tectonophysics 78:249-292

Lee JH, Ahn JH, Peacor, DR (1985a) Textures in layered silicates: Progressive changes through diagenesis and low temerpature metamorphism. J Sediment Petrol (in press)

Lee JH, Ahn JH, Yau LYC, Peacor DR (1984) Diagenesis of clay minerals from early burial through greenschist facies metamorphism: TEM/AEM studies. 21st Ann Meeting Clay Minerals Soc Abstr Progr: 76

Lee JH, Peacor DR (1983) Intralayer transitions in phyllosilicates of the Martinsburg Shale. Nature 303:608-609

Lee JH, Peacor DR (1985a) Ordered 1:1 interstratification of illite and chlorite: A transmission and analytical electron microscopy study. Clays Clay Mineral (submitted)

Lee JH, Peacor DR (1985b) The effect of diffusion on AEM analyses for $\mathrm{K}$ and other elements (in prep)

Lee JH, Peacor DR, Lewis DD, Wintsch RP (1983) Evidence for a solution-recrystallization origin of slaty cleavage at Lehigh Gap, Pennsylvania. Trans Am Geophys Union 64(18):319

Lee JH, Peacor DR, Lewis DD, Wintsch RP (1985b) Solutionrecrystallization origin of the slaty cleavage: TEM-AEM study of phyllosilicates from the Martinsburg Formation at Lehigh Gap, Pennsylvania. J Struct Geol (submitted)

Lee JH, Peacor DR, Wintsch RP (1982a) TEM and AEM study of changes in dioctahedral micas during slaty cleavage devolopment. Trans Am Geophys Union 63(18): 468

Lee JH, Peacor DR, Wintsch RP (1982b) TEM and AEM study of interlayering and along-layer transition in tri- and dioctahedral phyllosilicates. Geol Soc Am Abstr Progr 14(7):544

Lewis DD (1980) An investigation of the preferred orientation of phyllosilicates in the Martinsburg slate, Lehigh Gap area, Pennsylvania. Master thesis Indiana Univ Bloomington

Mackenzie RC, Walker GF, Hart R (1949) Illite occurring in decomposed granite at Ballater, Aberdeenshire. Mineral Mag 28:704

Maxwell DT, Hower J (1967) High-grade diagenesis and low-grade metamorphism of illite in the Precambrian Belt Series. Am Mineral 52:843-857

Minato H, Takano Y (1952) On the iron sericites and magnesium sericite from Unnan mine, Shimane Prefecture, Japan. Sci Papers College General Education Univ Tokyo 2:189 (M.A. 12-221)
Nagelschmidt G, Hicks D (1943) The mica of certain coal-measure shale in South Wales. Mineral Mag 26:297

Page R, Wenk HR (1979) Phyllosilicate alteration of plagioclase studied by transmission electron microscopy. Geology 7:393-397

Roy AB (1978) Evolution of slaty cleavage in relation to diagenesis and metamorphism: a study from the Hunsrückschiefer. Bull Geol Soc Am 89:1775-1785

Sorby HC (1853) On the origin of slaty cleavage. Edinburgh New Philos J 55:137-148

Stephens MB, Glasson MJ, Keays RR (1979) Structural and chemical aspects of metamorphic layering development in metasediments from Clunes, Australia. Am J Sci 279:129-160

van der Pluijm BA, Kaars-Sijpesteijn CH (1984) Chlorite-mica aggregates: morphology, orientation, development and bearing on cleavage formation in very-low-grade rocks. J Struct Geol $6: 399-407$

Veblen DR (1983) Microstructures and mixed layering in intergrown wonesite, chlorite, talc, biotite and kaolinite. Am Mineral $68: 566-580$

Velde B (1965) Phengite micas: synthesis, stability, and natural occurrence. Am J Sci 263:886-913

Velde B (1977a) A proposed phase diagram for illite, expanding chlorite, corrensite and illite-montmorillonite mixed layered minerals. Clays Clay Minerals 25:264-270

Velde B (1977b) Clays and clay minerals in natural and synthetic systems. Developments in Sedimentology 21, Elsevier Sci Pub Co, Amsterdam 218

Voll G (1960) New work on petrofabrics. Lpool Mnchr Geol J 2:503-567

Weaver, CE (1960) Possible uses of clay minerals in the search for oil. Clays Clay Mineral 8:Proc 8th National Conf Clays and Clay Minerals 214-227

Weber K (1981) Kinematic and metamorphic aspects of cleavage formation in very-low-grade metamorphic slates. Tectonophysics 78:291-306

White SH, Knipe RJ (1978) Microstructure and cleavage development in selected slates. Contrib Mineral Petrol 66:165-174

Williams PF (1972) Development of metamorphic layering and cleavage in low grade metamorphic rocks at Bermagui, Australia. Am J Sci 272:1-47

Wintsch RP (1978) A chemical approach to the preferred orientation of mica. Geol Soc Am Bull 89:157-180

Woodland BG (1982) Gradational development of domainal slaty cleavage, its origin and relation to chlorite porphyroblasts in the Martinsburg Formation, eastern Pennsylvania. Tectonophysics 82:89-124

Yoder HS, Eugster HP (1955) Synthetic and natural muscovites. Geochim Cosmochim Acta 8:225-280

Accepted September 24, 1984 